\title{
Western Ranching at the Crossroads
}

\author{
Jerry L. Holechek
}

\begin{abstract}
A s we enter the $21^{\text {st }}$ century, $\triangle$ rangeland livestock grazing in 1 the western United States confronts a highly uncertain and precarious future. Current challenges to western ranching include rapid urbanization, declining profitability, escalating concern over endangered species, uncertain knowledge of land use trends and land condition, noxious plant invasion, and growing environmental opposition to public land grazing. It is my hope that this article will result in better quantification of problems confronting western ranchers and stimulate more thinking on how they might be resolved.
\end{abstract}

\section{A Brief Historical Perspective}

To develop this subject, I consider some historical understanding essential. I refer the reader to Stoddart and Smith (1943), Hess (1992), Donahue (1999), and Holechek et al. (2000) for detailed accounts of the history of public land grazing in the western United States from differing perspectives. Rather than go through the various pieces of legislation and specific historical events, I will give my views on changes I have observed in public land ranching over the past 30 years (1970s through 1990s). Various members of my family were closely tied to public land ranching in eastern Oregon. In my youth (1960s) I witnessed large scale conversion of degraded sagebrush rangelands to crested wheatgrass pastures. The large increases in grazing capacity associated with these conversions were viewed as a wonderful thing by my grandad, uncles, and parents, whose ranches varied in size from small to large. When I took college range management classes in the 1970s, there was a heavy orientation towards brush control, seeding, water development, and rotation grazing systems. This orientation was in step with the widely held view that food production on every acre would need to be maximized to feed a rapidly expanding human population. The idea of using stocking rate reduction as a range improvement tool was almost unthinkable. Keep in mind the 1970s were a period of sky rocketing inflation and it was generally believed that food scarcity would be a serious threat to human welfare before the beginning of the $21^{\text {st }}$ century. Rising food prices during the late 1960s and 1970s resulted in political support for various cost subsidies to increase red meat output on public and private rangelands. In this period, large portions of the western Great Plains were being rapidly converted to cropland.

In 1980, when I first began teaching range management at New Mexico State University, the United States was on the verge of tremendous economic change that would persist to the present. Ronald Reagan was elected president in 1980 and he had a very different approach to running the economy than recent presidents (Johnson, Nixon, Ford, Carter). His administration implemented a package of programs involving tax reductions, tight monetary policy, increased defense spending, free trade incentives, and business deregulation that ended the stagflation of the 1970s (see Holechek et al. 2000). These changes, along with favorable climatic conditions, caused food shortages to turn into chronic food surpluses. The real price of beef adjusted for inflation has been in a downward trend since 1980 . However, real ranching costs have gone upward. This has severely reduced ranching profitability unless income was generated from other enterprises, such as recreation.

\section{Prosperity and the Shrinkage of Open Space}

During the 1990s the United States has experienced a period of extended prosperity unrivaled in its history. This has resulted from numerous technological breakthroughs as well as a global trend towards democratic, market oriented economics. Great wealth has been created by the unprecedented run up in the stock market from 1982 to 1999 . During this same period large scale demographic shift occurred from the eastern to western United States. About $16 \%$ more people now live in the 11 western states than in 1990 . Various changes in communication systems have made the world much smaller and far more accessible. Improved communications, rising affluence, and demographic shift have created tremendous demand for western rangeland as home sites and ranchettes. This has elevated private rangeland property values several fold over what they would be merely for grazing. Rangeland fragmentation into home sites and ranchettes is now ubiquitous in several western states. In areas such as central Colorado, central Texas, southern Arizona, central Utah, and central Oregon former ranching economies have been almost completely transformed into seemingly endless tracts of low density urban sprawl (Figure 1). Large ranching areas with low levels of subdivision still exist throughout Wyoming, southwest Texas, most parts of New Mexico, eastern Nevada, southeastern Oregon, and eastern Montana. However, if current land use and demographic trends continue, these areas could be threatened or disappear over the next 20 to 50 years.

\section{How Much Land Are We Losing?}

There are about 1.1 billion acres of rangeland in the United States. This involves 400 million acres of private and 700 million acres of public rangeland. Based on USDA-NRCS reports 


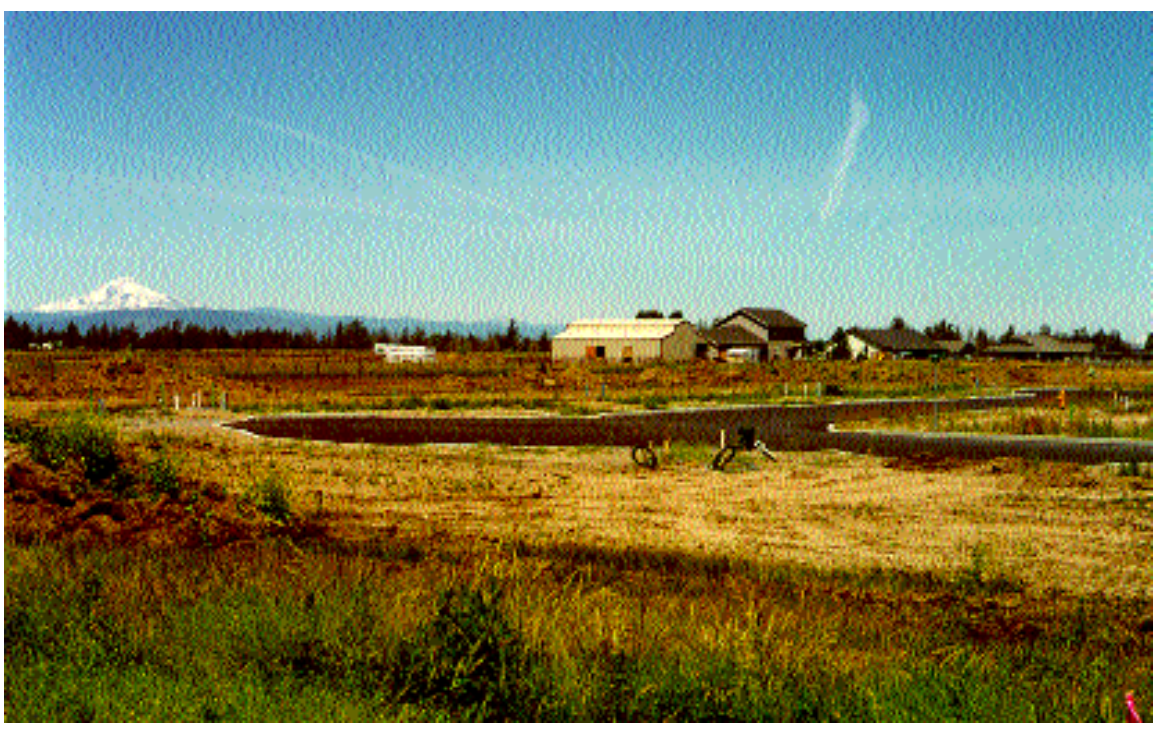

Fig. 1. Conversion of a central Oregon ranch into housing in July 2000. The author observed widespread conversions of rangeland to urban housing and ranchettes on a circular trip through California, Oregon, Nevada, Arizona, and New Mexico in summer 2000.

and other fragmented information, 2-3 million acres of rangeland may now be lost per year in the 11 western states and another million are lost in the Great Plains. Texas, now losing about 250,000 acres per year, has the highest rangeland losses to urbanization. It is the accelerating trend in losses that is most disturbing. Data from USDA-NRCS (1997) indicate total rangeland losses were about 1 million acres per year for the 1982-1992 period. However losses may be 3-4 million acres presently (Figure 1). Western states with the most rapid rates of rangeland loss are Texas, Arizona, Colorado, and California.

It is my opinion that the magnitude of rangeland losses to urbanization and fragmentation is uncertain. The first problem is that uniform, annual survey techniques across the United States are not applied. Another problem is that surveys such as those by the USDANatural Resources Conservation Service (1997) do not fully quantify land that is removed from production and left idle (ungrazed) by scattered development. For every 1 acre lost to subdivisions directly another 3 to 10 acres may be lost from the ranching base due to fragmentation (see Liffman et al. 2000). This, however, needs to be studied. Development of sound solutions to any problem depends on knowing the magnitude, location, and rate of change in factors causing the problem.

\section{Ranching Problems on the Urban Fringe}

Scattered subdivisions that extend 30 to 60 miles from metropolitan areas such as Phoenix, Tucson, Denver, Salt Lake City, El Paso, and Albuquerque severely compromise remaining ranches by increasing property taxes; vandalism; restrictions on management practices such as burning, weed control and predator control; marauding dog problems; trespass; carelessness with gates and fences; loss of livestock from theft and vehicle accidents; and liability (Huntsinger and Hopkinson 1996). We are increasingly encountering all of these problems on the New Mexico State University Chihuahuan Desert Rangeland Research Center 15 miles north of Las Cruces. Large scale rangeland fragmentation now extends 20 miles or more along all major roads that radiate from Las Cruces. El Paso and Las Cruces are now almost completely connected into a linear metroplex about 80 miles in length and 5-10 miles in width. Bureau of Land Management rangelands bordering the metroplex are generally scheduled for future development. Because there is little long term land use planning, I foresee no end to this accelerating trend of rangeland conversion.

\section{Other Problems from Rangeland Conversion}

I recognize that land development is an important part of progress, and that the changes previously described may, in many cases, be beneficial to human welfare. However, it troubles me that the haphazard, poorly planned pattern of development occurring in several western states is so wasteful of both space and water resources. Continuation of the present patterns of western land development may result in many future environmental and economic problems.

Infrastructure (roads, electricity, sewage, water, telecommunications) costs for low density housing associated with urban sprawl, scattered subdivisions, and 10 to 40 acre ranchettes are typically 2 to 4 times those associated with high density housing within city or town perimeters. These costs are rapidly driving up property taxes in many western counties. The long commutes associated with scattered land development increase pressure on existing highways and demand for new roads and highways. These commutes also increase fossil fuel consumption and air pollution associated with motor vehicle travel. Another concern centers around depletion and contamination of ground water supplies. Water experts predict that many of the subdivisions in the southwestern USA will run out of water if another 1950s style drought should occur. Contamination of remaining ground water supplies is becoming a serious problem in some areas.

\section{Livestock Grazing Versus Other Uses}

The shrinkage of private rangeland in the western states and rapidly growing human populations has made public rangelands more valuable for products such as wildlife, recreation, 
water, esthetics, clean air, and habitat for endangered species. This is the central argument in the recent book by Donahue (1999) that challenges public land grazing. The fact that controlled livestock grazing is generally compatible with other public land uses does not seem well understood and accepted by many of the newcomers to western communities (Liffman et al.). Ranchers and range managers need to better convince the public of the benefits of public land ranching. Here I favor more aggressive efforts by the Land Grant University extension systems to reach the public at large. I believe the greatest opportunities to communicate sound information exist within the public school system. I consider it more important to reach the teachers than the students because of their great capability to influence both young people and adults.

\section{Declining Profitability}

Next to shrinkage of the land base, I consider the most alarming trend confronting public land ranching to be the rather precipitous drop in its profitability. Based on New Mexico State University reports most public land ranches in New Mexico have lost money since 1994 due to rising ranching costs, low cattle prices, and drought.

On the bright side, some ranchers have found they can substantially increase their incomes through diversification into recreational enterprises such as fee hunting, pack trips, bed and breakfast, dude ranching, and so on. However, many risks and uncertainties are associated with these enterprises. Liability is one such risk. Sound marketing skills are usually needed for a successful recreational enterprise.

\section{Uncertain Knowledge of Range Condition}

Limited information is available on public and private rangeland health in the United States. Assuming data collected by the Bureau of Land Management is accurate, substantial improvement occurred from 1975 to

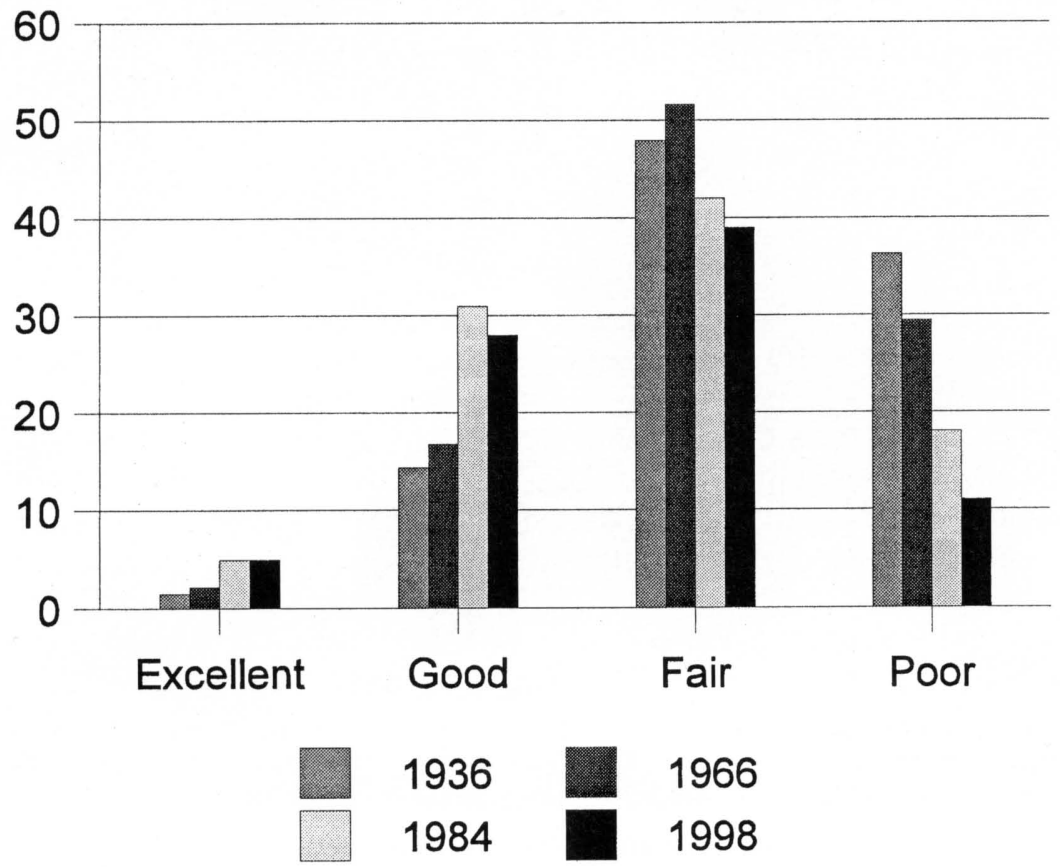

Fig. 2. Comparative percentages of Bureau of Land Management rangelands in Excellent, Good, Fair, and Poor condition between 1936 and 1998. Totals equal less than 100\% because some lands have not been rated as to range condition. Source: United States Department of Interior-Bureau of Land Management Annual Reports.
1984, but no real change has occurred since 1984 (Figure 2). On private rangeland, NRCS data indicate little change in rangeland condition since 1977 (Figure 3).
Long-term studies (50 year) are evaluating the status of Chihuahuan Desert Rangelands across 40 sites in southern New Mexico (Galt et al. 1999). Little change has occurred in

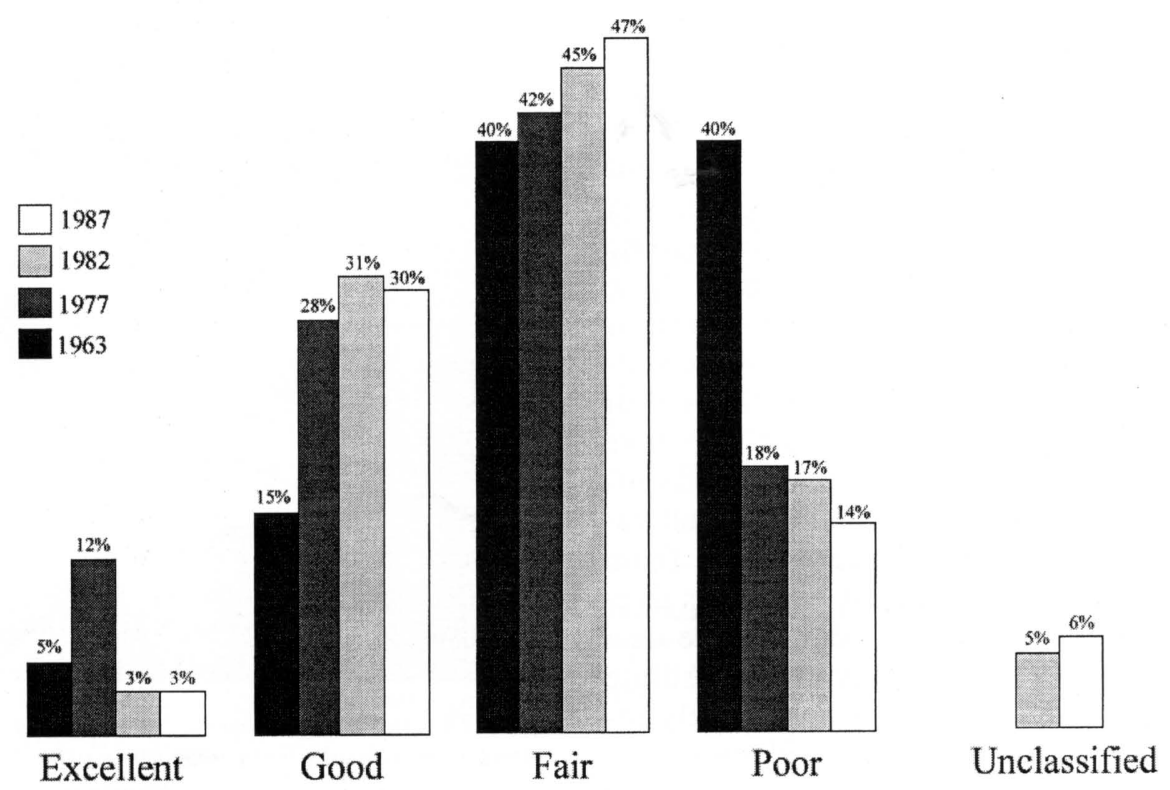

Fig. 3. Comparative percentages of private rangeland in excellent, good, fair, and poor condition from 1963 to 1987 (data from the USDA-Natural Resources Conservation Service). 


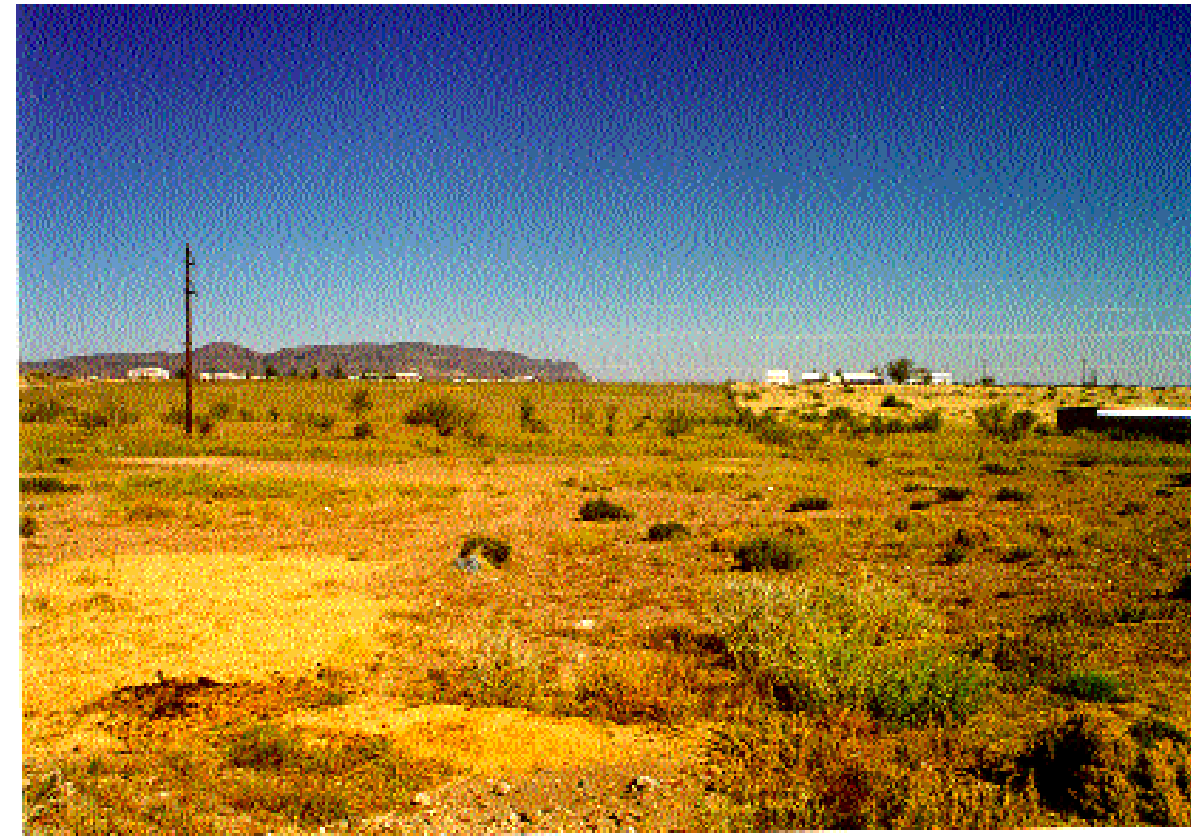

Fig. 4. Rangelands near cities and major highways are much more fragmented and have higher proportions that are in low ecological condition and are overgrazed than those in remote loca tions. Noxious plant invasion is a serious problem on this fragmented rangeland in southwest ern Texas. grazed while the Gila National Forest in south-western New Mexico is largely in mid seral condition and receives moderate to heavy grazing intensities. A big part of the problem on the Gila is widespread pinyon-juniper invasion and large increases in elk populations over the past 25 years. Although these problems have not been caused by ranching, they definitely affect the economic viability of ranching.

On numerous trips through the California annual grassland I have noticed very little overgrazing (Figure 5). I believe research-extension efforts to promote residue based range management explains the high condition of these rangelands. My recent experiences in New Mexico indicate that educational programs can be quite effective in convincing ranchers to conservatively stock and maintain residual vegetation for watershed, vegetation, and wildlife habitat protection.

\section{Some Final Thoughts}

ecological condition in 1952 compared to 1999 . However, there was considerable change within decades, primarily due to climatic variability.

This same survey attempted to characterize the extent of the overgrazing problem. Estimates have varied considerably among locations and years. Fragmented rangelands near cities and major travel corridors had much lower ecological condition scores and more overgrazing than those in remote areas, in large tracts, and away from major roads. About 15 to $20 \%$ of the rangeland was considered heavily grazed in remote areas while along major highways and near cities 40 to $50 \%$ was heavily grazed. Noxious plant invasion was a much more serious problem on the rangelands near towns and cities than those in remote areas (Figures 4). This is due to disturbances such as road building, cultivation, and severe overgrazing from using small rangeland parcels as livestock holding areas. While these data may have limitations in an absolute context, I believe they accurately reflect the impacts of development on the overgrazing problem.

It is my observation that rangeland conditions vary tremendously within and between states. As an example, most of the Coronado National Forest in southern Arizona is in a high seral condition and lightly to conservatively
Shrinkage in the land base, declining ranching profitability, the anti-grazing

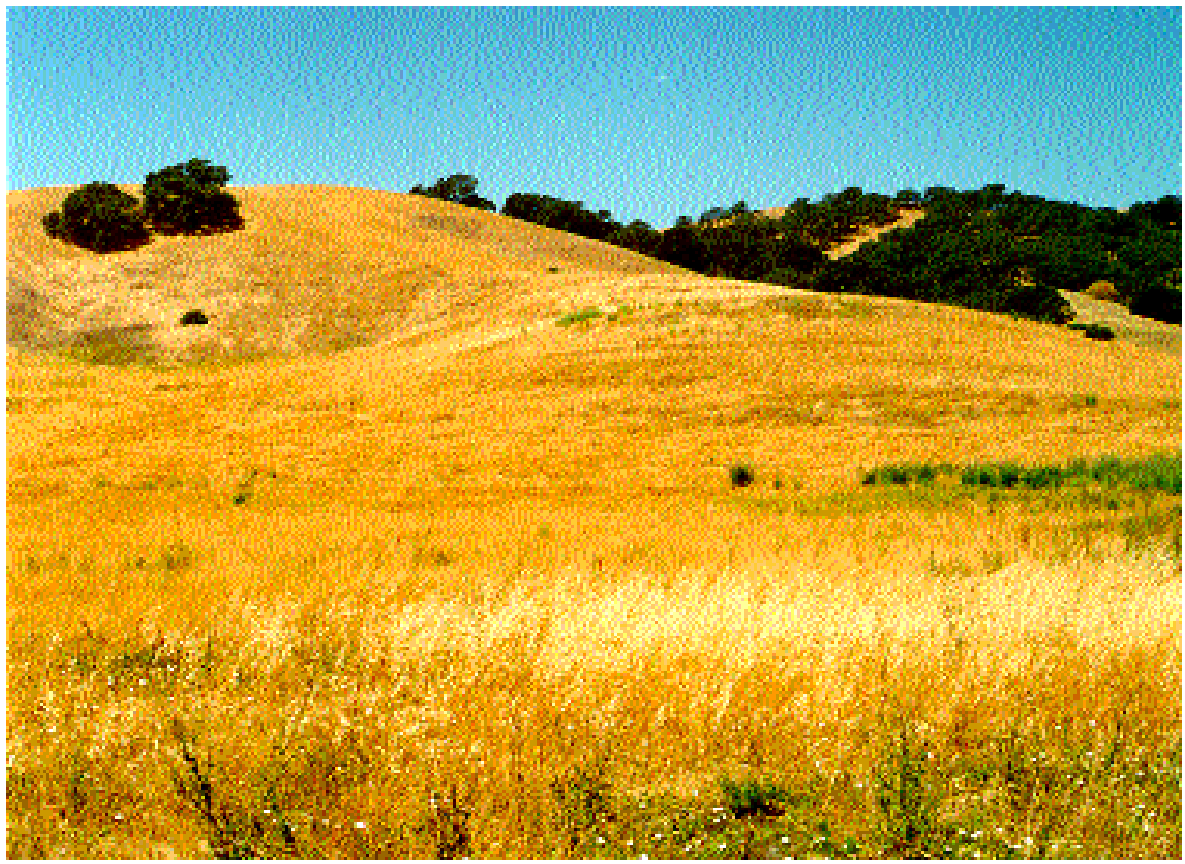

Fig. 5. The author has observed very little overgrazing in various trips through the California annual grasslands. Even near large urban areas such as San Francisco (above photo) annual grassland rangelands are generally quite well managed. The author attributes this to well thought out research-extension programs by the California land grant universities. 
movement, and rangeland degradation from brush and noxious plant invasions interact to seriously imperil the future of western ranching. To resolve these problems, better information is needed on trends in rangeland uses, extent of overgrazing problems, and rangeland ecological condition. The amount of remaining rangeland in the western United States, as well as the actual annual loss rate, are both subject to question. Models are needed that project future land use patterns under different demographic, economic, regulatory, and temporal scenarios. The public needs to be better informed on the rate of loss of rangelands and on the benefits of rangelands and ranching. It is my observation that the importance of rangelands in providing products such as open space, clean water, clean air, biodiversity, esthetics, recreation, and wildlife are not well understood. Difficult choices will have to be made sooner or later on the issue of protecting private property rights versus protecting large landscapes in a relatively underdeveloped state for their ecosystem services. With appropriate technology, ranching can enhance many environmental and social values and is compatible with most others (see Huntsinger and Hopkinson 1996). We must better communicate the importance of rangelands and ranching to the public through the public education system.

Conservation easements are a means by which ranchers can transfer development rights to private organizations, such as The Nature Conservancy or state and local governments, for monetary compensation and/or tax breaks. Some western states, such as California, now provide tax breaks to ranchers who own rangelands with important ecological and/or scenic values, and agree to not develop these areas. I believe conservation easements will become very important in rangeland preservation in the twenty-first century.

Ranching cooperatives offer considerable opportunity for small and medium sized ranchers to increase their profitability (Ward 1998). Although they generally require ranchers to give up some of their independence, this approach can greatly reduce ranch purchasing costs and improve marketing power.

I believe few western ranchers have taken advantage of the great opportunities to increase their incomes through diversification. Ward (1998) points out that diversification can include better ways to process and market traditional livestock products (meat) as well as diversification into other enterprises. It is my observation that ranch diversification into other enterprises, such as fee hunting, wildlife viewing, get-away-lodging, fee fishing, golfing, trail trips, and rodeo stock production is just starting its big take off. Better information is needed on the risks and rewards from these endeavors.

The rangeland resource base in the western United States is still quite vast. History shows that the amount of rangeland in the United States over the past 100 years has been somewhat unstable. Large-scale conversions to farmland occurred in the 1910s and 1970s while major farmland conversions back to rangeland occurred in the 1950s and 1980s. Former rangelands in the western United States near the large urban centers that have been converted to low density housing will probably never again be rangeland. However, problems relating to water and energy scarcity could reverse the conversion of the more remote and less scenic rangelands to ranchettes. Considerable farmland could be converted back to rangeland because of sale of water rights to urban users and depletion of aquifers.

I believe that western rangelands over the next 100 years will probably shrink by 25 to $40 \%$. This is due to an expected doubling of the human population in the United States from 280 million now to 560 million in 2100 and continued demographic shift to the West. However, this still leaves a land base of 700 million acres, which is substantial. Better management of remaining rangelands through brush control, seeding, controlled burns, and improved grazing techniques have great potential to increase their productivity for livestock, water, wildlife, and other amenities, largely offsetting the loss of the land base. Individual rancher survival will depend on their capability to take advantage of the opportunities associated with social and demographic change.

\section{Literature Cited and Other Reading}

Donahue, D. L. 1999. The Western Range Revisited. University of Oklahoma Press, Norman, OK.

Galt, D., J. Navarro, J. McCormick, and J. L. Holechek. 1999. Forty-six year trend in range condition in southwestern New Mexico. Livestock Research Briefs and Cattle Growers' Short Course. New Mexico State Univ. Coop. Ext. Serv., Las Cruces, N.M.

Hess, K., Jr. 1992. Visions upon the land. Island Press, Covelo, Calif.

Holechek, J. L. R. Cole, J. Fisher, and R. Valdez. 2000. Natural Resources: Ecology, Economics, and Policy. Prentice-Hall, Upper Saddle River, NJ.

Huntsinger, L. and R. Hopkinson. 1996. Viewpoint: Sustaining rangeland landscape: A social and ecological process. J. Range Manage. 46:167-173.

Liffman, R. H., L. Huntsinger, and L. C. Forero. 2000. To ranch or not to ranch: Home on the range? J. Range Manage. 53:362-371.

Raymond, L. 1997. Viewpoint; Are grazing rights on public lands a form of private property? J. Range Manage. 50:341-438.

Stoddart, L. A. and A. D. Smith. 1943. Range Management. McGraw-Hill Book Company, New York, N.Y.

United States Department of Agriculture-Natural Resources Conservation Service. 1997. A Geography of Hope. U.S. Government Printing Office, Washington, D.C.

Ward, N. 1998. Sustainable ranching: a rancher's perspective.

Author is professor of range science, Department of Animal and Range Sciences, New Mexico State University, Las Cruces, New Mexico 88003. This paper was supported by the New Mexico Agricultural Experiment Station and was part of project 1-5-27417. 